\title{
ASIAKKAAN KOKEMUKSIA FYSIOTERAPEUTIN SUORAVASTAANOTOSTA SELKÄKIPUJEN VARHAISVAIHEESSA
}

\author{
Retrospektiivinen kuvaileva kyselytutkimus
}

\section{Johdanto}

Suomessa sosiaali- ja terveysalan uudistukset ovat hallinnollisten kysymysten lisäksi tuoneet ajankohtaisiksi kysymykset asiakkaan hoidon joustavasta linjauksesta, terveydenhuollon kustannusten järkevästä kohdentamisesta ja henkilöstön mielekkäästä työnjaosta (Ylinen \&t Nikander 2014). Terveydenhuollon kustannusten sairauskohtaisessa jakautumisessa tuki- ja liikuntaelinsairaudet ovat mielenterveyssairauksien ohella tilaston kärjessä (Pohjolainen ym. 2007). Selkäkivut ja niiden pitkittyminen, uusiutuminen ja kroonistuminen on nähty yhtenä tärkeänä haasteena terveydenhuollon toimintojen kehittämisessä (Pohjolainen ym. 2015).

Suomen terveyskeskuksissa on usean vuoden ajan kehitetty toimintaa, jossa selkäkipuisten asiakkaiden ensikontakti on fysioterapeutti sen jälkeen, kun vakavat sairaudet on seulottu pois vakioitujen kyselyiden avulla (Suominen 2015; Helsingin kaupunki, SOTE/ fysioterapia 2011). Suomen Fysioterapeuttien vuonna 2007 toteuttaman selvityksen mukaan fysioterapeuttien laajennettua tehtäväkuvaa oli toteutettu 29:ssä perusterveydenhuollon fysioterapiayksikössä (Kukka 2010). Toimintaa on kehitetty järjestämällä fysioterapeuteil- le eri mittaisia täydennyskoulutuksia vastaamaan suoravastaanoton tuomiin haasteisiin tuki- ja liikuntaelinsairauksien osalta (Lähteenmäki \&t Leppänen 2016). Toiminnasta on tehty henkilökunnan kokemuksiin perustuvia selvityksiä, ja asiakkaiden kokemuksista on tehty pilottikyselyjä (Suoyrjö ym 2016, Ylinen 2015, Kinnunen \&t Karvonen 2015, Ropponen \&t Troberg 2010, Kangas ym. 2015, Kylänen ym. 2015). Tulosten mukaan sekä henkilökunta että asiakkaat ovat olleet toimintaan tyytyväisiä. Näyttää siltä, että asiakkaat ovat kokeneet saaneensa selkäkivun hallintaan saamillaan ohjeilla. Lisää tutkimustietoa kuitenkin tarvitaan selkäkivun mahdollisesta uusiutumisesta ja sen syistä. Aiemmassa tutkimuksessamme selvitimme suoravastaanottotoimintaan osallistuvien fysioterapeuttien täydennyskoulutustiedon siirtymistä fysioterapeuttien suoravastaanottotoimintaan (Karvonen ym. 2015). Tulokset osoittivat, että kahdeksan päivän koulutuksen sisällön siirtyminen käytäntöön asiakkaan kliinisen tutkimisen ja johtopäätösten osalta oli hyvää tasoa.

Fysioterapian suoranvastaanotto toimii selkäkipuasiakkaan kohdalla siten, että hoidon tarvetta arvioidaan Suomessa kehitetyn mallin mukaan (Suoyrjö ym. 2016, Ylinen 2015). Mallin mukaan ajanvarauksessa pyritään 
kirjallisen ohjeistuksen avulla tunnistamaan vakavien sairauksien merkit eli se, pitääkö selkäkipuisen asiakkaan ensin käydä lääkärin vastaanotolla vai voiko hän mennä suoraan fysioterapeutin vastaanotolle. Fysioterapeutin suoravastaanotolla noudatetaan Käypä hoito -suositusta (Pohjolainen ym. 2015) ja Näyttöön perustuvaa tuki- ja liikuntaelinsairauksien ohjeistusta selkäkivun varhaisvaiheessa (Häkkinen ym. 2014). Suosituksena ovat:

1. Hyvä kliininen tutkiminen

2. Selkeä, ymmärrettävä selitys kivun mahdollisista syistä

3. Ohjaus kivun hoitoon

4. Nopea toimintakyvyn palauttaminen ja vaivojen uusiutumisen ehkäisy

5. Sairauslomatarpeen arviointi

Epäspesifın, akuutin selkävaivan spontaania paranemista tuetaan yksilöllisellä ohjauksella, jossa selän kuormitusta kevennetään ja paranemisen edetessä turvallisesti lisätään. Spontaania paranemista hidastavia kuormitustekijöitä voivat olla aikaisempaan selkäkipuun liittyvät negatiiviset kokemukset tai aikaisemmin saatu virheellinen tai puutteellinen tieto kivun syystä ja hoidosta (Linton Et Shaw 2011).

On olemassa selkeitä argumentteja suoravastaanoton puolesta ja sitä vastaan. Uusimman tutkimuksen valossa nykyistä käytäntöä olisi kuitenkin syytä tarkastella perusteellisesti muun muassa kustannustehokkuuden osalta. (Foster ym. 2012.) Suomessa tehdyn tutkimuksen mukaan nykykäytäntö, jossa selkäkivun varhaisessa vaiheessa on toteutettu aktiivista fysioterapiaa, on tehokkaampaa kuin pelkkä ohjeistus, kun tulosmittarina pidetään sairauspäivien määrää (Paatelma 2011). Tutkimuksessa ei ole kuitenkaan analysoitu kustannusvaikuttavuutta.

Fysioterapeutin varhaiselle interventiolle asetetut tavoitteet perustuvat tutkimuksiin, joita on tehty selkäkivun pitkittymisen syistä ja seurauksista, kuten liikkeen pelon vaikutuksesta ja liikkeiden hallinnan heikkoudesta (Moseley 2004, Moseley ym. 2004, Nijs \& Van Houdenhove 2009, Comerford \& Mottram 2001, O`Sullivan 2005, Luomajoki ym. 2008).
Varhain aloitettu fysioterapiainterventio selkäkivussa kaipaa kuitenkin lisää korkeatasoisia satunnaistettuja tutkimuksia kustannusanalyyseineen (Ojha ym. 2016).

Kipulääkkeiden osalta noudatetaan fysioterapeuttien suoravastaanoton toiminnan periaatteita toimipaikan vastuulääkärin antamien ohjeiden mukaan (Ylinen 2015, Kinnunen Et Karvonen 2015, Ropponen \&t Troberg 2010). Seurantakäynnillä arvioidaan mahdolliset toimintakykyä heikentävät tekijät ja ohjataan tarvittavat harjoitteet toimintakyvyn palauttamiseksi ja mahdollisimman nopean työhön paluun mahdollistamiseksi (Paatelma 2011).

Tämän tutkimuksen tarkoituksena oli selvittää asiakkaan tilannetta ja kokemuksia noin kolmen kuukauden kuluttua hänen käynnistään fysioterapeutin suoravastaanotolla. Kirjallisella kyselyllä selvitettiin selkäkivun mahdollista uusiutumista, asiakkaan käsityksiä uusiutumisen syistä, kivun hoito-ohjeiden ja omaharjoitteiden toteutumista, selkäkipuun liittyvän pelon vähenemistä, uudelleen fysioterapeutille tai lääkärille hakeutumista sekä sairauslomalla oloa.

\section{Aineisto ja menetelmät}

Tutkimus oli retrospektiivinen, kuvaileva kyselytutkimus, joka toteutettiin strukturoidulla kyselylomakkeella (liite).

Sataviisikymmentä (15-82-vuotiasta) selkäkipuasiakasta poimittiin järjestyksessä niiltä pääkaupunkiseudun terveysasemilta, joilla fysioterapeuttien suoravastaanotto oli jo vakinaistettu. Vastausten analysoinnissa asiakkaat jaettiin kolmeen ryhmään: eläkeläisiin, työttömiin sekä työssä olevien tai opiskelevien ryhmään. Ryhmittely perustui työmarkkinaaseman statukseen sillä perusteella, että työssä olevat ja opiskelijat muodostavat niin sanotun aktiivisen populaation verrattuna työttömiin sekä eläkeläisiin. Asiakkaiden ensikäynnistä fysioterapeutin vastaanotolla oli kyselyyn valinnan aikaan kulunut kolme kuukautta. Asiakkaiden poiminnan asiakasrekisteristä teki kevään 2015 aikana terveyskeskuksen osastonhoitaja, jolla oli tähän terveyskeskuksen hallinnolta saatu lupa. Kun määräaikaan men- 


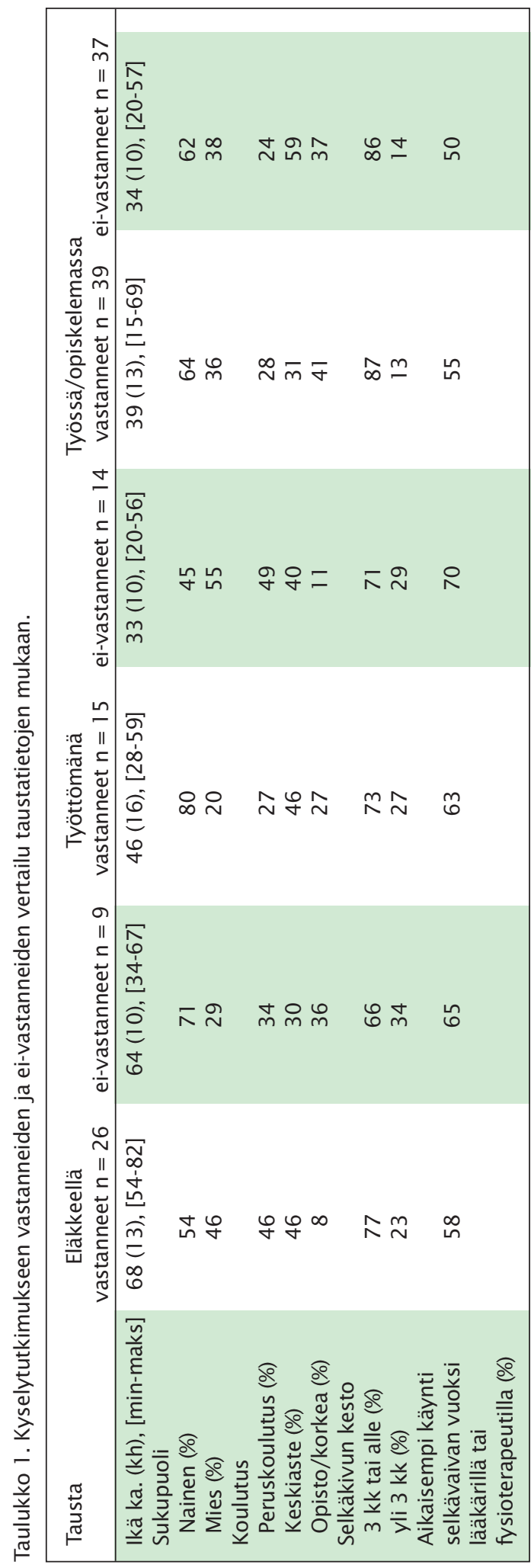

nessä vastauksia oli palautunut 45 prosenttia, lähetettiin kaikille uusintakysely ja vieraskielisille asiakasnimille kyselyn ohjeistus myös englanninkielisenä. Kyselyt postitettiin terveyskeskuksesta, jonne vastaukset myös palautettiin. Kyselyyn vastattiin nimettömästi. Tutkimuksen suorittamiseen saatiin terveyskeskuksen hallinnolta eettisen arviointikäytännön mukainen lupa (HEL 2015-000350 T 130201).

Aineiston tilastoanalyysit tehtiin SPSS-tilasto-ohjelmalla. Ryhmien välisiä järjestysasteikollisia muuttujia testattiin yksisuuntaisella varianssianalyysillä (Oneway Anova), joka varmistettiin nonparametrisellä testillä (Kruskal-Wallis). Kahden ryhmän tapauksessa testattiin riippumattomien otosten t-testillä ja vastaavalla nonparametrisellä testillä (MannWhitney). Luokitteluasteikolliset muuttujat testattiin ristiintaulukoinnilla ja khii toiseen -riippumattomuustesteillä. Muuttujien välistä korrelaatiota tarkasteltiin Pearsonin korrelaatiokertoimella. Avointen kysymysten vastaukset litteroitiin ja niitä ryhmiteltiin temaattisiksi kokonaisuuksiksi.

\section{Tulokset}

Vastauksia palautettiin määräaikaan mennessä 80 (53 \%). Kyselyn saaneista noin 20 prosenttia oli muualta maahan muuttaneita, joiden äidinkieli ei ollut suomi tai englanti. Kyselyyn vastanneet ja vastaamatta jättäneet eivät eronneet taustamuuttujien osalta tilastollisesti toisistaan. Taulukossa 1 on vastanneiden ja vastaamatta jättäneiden (ei-vastanneiden) taustatiedot ryhmittäin: eläkeläiset, työttömät sekä työssä olevat tai opiskelijat.

\section{Ryhmien välinen vertailu}

Käynnit lääkärin tai fysioterapeutin luona. Vastanneiden ja ei-vastanneiden ryhmien välillä ei ollut eroa aikaisemman selkävaivan vuoksi lääkärin tai fysioterapeutin vastaanotolla käyneissä (taulukko 1). Yli puolet vastaajista oli käynyt joskus aiemmin fysioterapeutin luona ja kaksi kolmesta lääkärin luona (kysymykset 12 ja 13, taulukko 2). Esitietolo- 
makkeeseen merkitty kivun kesto vaihteli eri ryhmissä yhdestä viikosta yli kolmeen kuukauteen. Eniten kivun kestoltaan akuutteja ja subakuutteja vaivoja oli työssä olevien ja opiskelijoiden ryhmässä (taulukko 1).

Käynnistä koettu apu selkävaivaan. Kaikissa vastanneiden ryhmissä neljä viidestä (80 \%) koki saaneensa paljon tai kohtalaisesti apua selkävaivaansa (kysymys 15, taulukko 2).

Kivun hoito-ohjeiden ja harjoitteiden noudattaminen. Asiakkaat kaikissa ryhmissä ilmoittivat toteuttaneensa fysioterapeutin antamia kivunhoito-ohjeita hyvin tai kohtalaisesti (ryhmittäin 85-87 \%) (kysymys 17, taulukko 2). Ryhmien välillä ei ollut tilastollisesti merkitsevää eroa, p=0,965. Kuitenkin noin puolet niistä, jotka eivät kokeneet saaneensa apua selkävaivaansa, ilmoitti jättäneensä noudattamatta saamiansa kivunhoito-ohjeita. Fysioterapeutin antamia harjoitteita oli noudatettu yli 80-prosenttisesti kaikissa ryhmissä (kysymys 22, taulukko 2). Ryhmien välillä ei ollut tilastollisesti merkitsevää eroa, $\mathrm{p}=0,888$.

Selkäkipuun liittyvä pelko. Noin kolmasosa kaikissa ryhmissä ei kokenut selkäkipuun liittyvää pelkoa. Fysioterapeutilla käynnin jälkeen pelko oli pääsääntöisesti vähentynyt niillä, jotka olivat kokeneet pelkoa (11-26 \%) (kysymys 19 , taulukko 2), $\mathrm{p}=0.707$. Pelkoa kokeneista eläkeläisistä ja työssä olevista/opiskelijoista 71-80 prosenttia kertoi päässeensä pelosta, mutta pelkoa kokeneista työttömistä 40 prosenttia ilmoitti, ettei pelko ollut poistunut fysioterapeutin luona käynnin jälkeen.

Kivun uusiutuminen fysioterapeutilla käynnin jälkeen. Kolmen kuukauden aikana selkäkivun uusiutuminen oli vähäisintä työssä olevien ja opiskelijoiden ryhmässä (15\%) ja suurinta eläkeläisten ryhmässä (30\%), $\mathrm{p}=0,503$ (kysymys 25, taulukko 2). Kysyttäessä asiakkaan käsityksiä kivun uusiutumisen syistä (kysymys 34, liite) vastauksissa tuotiin esille laiskuus tehdä harjoitteita, heikot vatsalihakset, vähäinen liikunta, kulumat ja huono ryhti.
Sairauspoissaolot ja uudelleen vastaanotolle hakeutuminen. Työssä olevien ja opiskelijoiden ryhmästä vain yksi henkilö ilmoitti olevansa kyselyhetkellä sairauslomalla (kysymys 28, taulukko 2). Saman selkäongelman vuoksi asiakkaista hakeutui uudelleen fysioterapeutille 4-15 prosenttia ja lääkärille 0-11 prosenttia (kysymys 30 ja 31, taulukko 2), $p=0,882$.

Selkäkivun uusiutuminen, selkäkipuun liittyvä pelko ja harjoittelu. Kolmen kuukauden aikana selkäkivun uusiutuminen oli vähäistä. Kipu oli uusiutunut 17:llä kaikista kyselyyn vastanneista 80 henkilöstä. Yhteistä heille oli, ettei fysioterapeutilla käynti vähentänyt heidän selkäkipupelkoaan, ja samat henkilöt ilmoittivat käyneensä myös aikaisemmin selkäkipunsa vuoksi lääkärillä ja/tai fysioterapeutilla. Näistä seitsemästätoista henkilöstä kuusi ilmoitti, ettei ollut tehnyt saamiaan harjoitteita tai että oli jättänyt noudattamatta saamiansa kivunhoito-ohjeita. Aikaisempi selkäkipu oli tilastollisesti merkitsevin selittävä tekijä selkäkivun uusiutumiselle $(\mathrm{p}=0,011)$.

Särkylääkkeiden käyttö selkäkipuun. Särkylääkkeiden käytössä selkäkivun hoidossa oli eroja. Eläkeläisistä ja työttömistä käytti satunnaisesti tai päivittäin särkylääkkeitä 62-67 prosenttia, kun taas työssä olevista ja opiskelijoista 29 prosenttia (kysymys 33, taulukko 2), $p=0,446$.

\section{Tulosten tarkastelu}

Suurin osa kysymyksistä oli dikotomisia ( 1 = kyllä, 2 = ei), ja ne kolmiportaiset kysymykset (kysymykset 15, 17, 19, 25 ja 33), joita tutkimuksessa tarkasteltiin $(1$ = paljon, 2 = kohtalaisesti, 3 = ei lainkaan) muutettiin kaksiportaisiksi $(1=$ paljon/kohtalaisesti, $2=$ ei lainkaan) raportoinnin yksinkertaistamiseksi.

Suurin osa kyselyyn vastanneista, fysioterapeuttien suoravastaanotolla käyneistä selkäkipuasiakkaista koki hyötyvänsä fysioterapeutin kivunhoito-ohjeista ja muusta paranemista tukevasta sekä toimintakykyä ylläpitävästä neuvonnasta ja ohjauksesta, joka 
Taulukko 2. Vastausten jakaumat ryhmittäin keskeisten kysymysten osalta.

\begin{tabular}{|c|c|c|c|c|c|c|c|}
\hline \multirow[t]{2}{*}{ Kysymys } & \multicolumn{2}{|l|}{$\begin{array}{c}\text { Eläkeläiset } \\
n=26\end{array}$} & \multicolumn{2}{|l|}{$\begin{array}{c}\text { Työttömät } \\
n=15\end{array}$} & \multicolumn{2}{|c|}{$\begin{array}{c}\text { Työssä/opisk. } \\
\mathrm{n}=39\end{array}$} & \multirow{2}{*}{$\begin{array}{c}\text { ryhmäerot } \\
\text { - p-arvo }\end{array}$} \\
\hline & Kyllä \% (n) & Ei \% (n) & Kyllä \% (n) & Ei \% (n) & Kyllä \% (n) & $\mathrm{Ei} \%(\mathrm{n})$ & \\
\hline $\begin{array}{l}\text { 12. Oletteko käynyt } \\
\text { aiemmin selkävaivan } \\
\text { vuoksi lääkärillä? }\end{array}$ & $62(16)$ & $38(10)$ & $73(11)$ & $27(4)$ & $56(22)$ & $44(17)$ & 0,893 \\
\hline $\begin{array}{l}\text { 13. Oletteko käynyt } \\
\text { aiemmin selkävaivan } \\
\text { vuoksi fysioterapeutilla? }\end{array}$ & $54(14)$ & $46(12)$ & $53(8)$ & $47(7)$ & $54(21)$ & $46(18)$ & 0,882 \\
\hline $\begin{array}{l}\text { 15. Oliko käynnistä } \\
\text { fysioterapeutin } \\
\text { vastaanotolla apua } \\
\text { selkävaivassanne? }\end{array}$ & $81(21)$ & $19(5)$ & $80(12)$ & $20(3)$ & $82(32)$ & $18(7)$ & 0,893 \\
\hline $\begin{array}{l}\text { 17. Oletteko pystynyt } \\
\text { toteuttamaan } \\
\text { fysioterapeutin } \\
\text { teille neuvomia } \\
\text { kivunhoitotapoja? }\end{array}$ & $85(22)$ & $15(4)$ & 87 (13) & $13(2)$ & $85(33)$ & $15(6)$ & 0,965 \\
\hline $\begin{array}{l}\text { 19. Vähensikö } \\
\text { fysioterapeutin } \\
\text { luona käynti } \\
\text { selkäkipuun } \\
\text { liittyvää pelkoa? }\end{array}$ & $89(23)$ & $11(3)$ & $74(11)$ & $26(4)$ & $80(31)$ & $20(8)$ & 0,707 \\
\hline $\begin{array}{l}\text { 22. Oletteko tehneet } \\
\text { fysioterapeutin } \\
\text { teille ohjaamia } \\
\text { harjoitteita? }\end{array}$ & $85(22)$ & $15(4)$ & 93 (14) & $7(1)$ & $87(34)$ & $13(5)$ & 0,902 \\
\hline $\begin{array}{l}\text { 25. Onko selkävaivanne/ - } \\
\text { kipunne uusiutunut } \\
\text { fysioterapeutilla } \\
\text { käyntinne jälkeen? }\end{array}$ & $30(8)$ & $70(18)$ & $20(3)$ & $80(12)$ & $15(6)$ & $85(33)$ & 0,503 \\
\hline $\begin{array}{l}\text { 28. Oletteko nyt } \\
\text { sairauslomalla saman } \\
\text { selkävaivan vuoksi? }\end{array}$ & $4(1)$ & $96(25)$ & $0(0)$ & $100(15)$ & $3(1)$ & $97(38)$ & 0,603 \\
\hline $\begin{array}{l}\text { 30. Oletteko hakeutunut } \\
\text { uudelleen fysioterapeutin } \\
\text { vastaanotolle uusiutuneen } \\
\text { selkävaivanne vuoksi? }\end{array}$ & $4(1)$ & $96(25)$ & $13(2)$ & 87 (13) & $15(6)$ & $85(33)$ & 0,882 \\
\hline $\begin{array}{l}\text { 31. Oletteko hakeutunut } \\
\text { uudelleen lääkärille } \\
\text { uusiutuneen } \\
\text { selkävaivanne vuoksi? }\end{array}$ & $11(3)$ & $89(23)$ & $0(0)$ & $100(15)$ & $10(4)$ & $90(35)$ & 0,806 \\
\hline $\begin{array}{l}\text { 33. Käytättekö } \\
\text { selkäkipuunne } \\
\text { nyt särkylääkkeitä? }\end{array}$ & $16(62)$ & $10(38)$ & $10(67)$ & $5(33)$ & $11(29)$ & $28(71)$ & 0,446 \\
\hline
\end{tabular}


oli yksilöity fysioterapeutin kliinisten tutkimistulosten mukaan. Ainoastaan 13 prosenttia vastaajista joutui hakeutumaan uudelleen fysioterapeutille ja 15 prosenttia lääkärille uusiutuneen selkävaivan vuoksi kolmen kuukauden aikana. Vain yksi henkilö työssä olevien ja opiskelijoiden ryhmästä oli sairauslomalla kyselyyn vastaamisen aikaan. Merkitsevin selittävä tekijä kivun uusiutumiselle oli aikaisempi selkäkipu. Mielenkiintoista olisi tarkastella seurantakyselyllä mahdollista kivun uusiutumista vielä, kun on kulunut vuosi fysioterapeutilla käynnistä. Tuoreessa systemaattisessa kirjallisuuskatsauksessa todetaan selkäkivun uusiutumisen riskin olevan 33 prosentin luokkaa, mutta uusiutumisen syitä ei tässä katsauksessa pystytty selvittämään (da Silva ym. 2017).

Tutkimuksemme tulokset vahvistavat aiempia pilottitutkimusten tuloksia asiakkaiden tyytyväisyydestä fysioterapeuttien suoravastaanottoon (Kinnunen \&t Karvonen 2015). Asiakkaiden omat maininnat kivun uusiutumisen mahdollisista syistä, kuten laiskuus tehdä harjoitteita tai vähäinen liikunta, antavat aiheen panostaa ohjauksessa entistä enemmän liikunnan harrastamisen motivaatioon. Tämän tutkimuksen tulosten mukaan selkäkivun uusiutumisella ja harjoitteiden suorittamatta jättämisellä näyttäisi olevan yhteys. Useissa aikaisemmissa tutkimuksissa tärkeinä toimintakyvyn ylläpitämisen keinoina on esitetty terapeuttinen harjoittelu ja säännöllinen liikunta (Pohjolainen ym. 2015). Tuloksia tulkittaessa näyttäisi siltä, että fysioterapeuttien suoravastaanotossa selkäkipuasiakas on kokenut saaneensa apua selkävaivaansa, mutta ohjauksessa pitäisi tehostaa vielä enemmän asiakkaan motivoimista pitkäkestoiseen harjoitteluun. Tämä havainto korostaa suoravastaanottotoiminnan seurantakäyntien tärkeyttä. Ensimmäisellä tapaamiskerralla tavoitteena on hyvä kliininen tutkiminen, selkeä, ymmärrettävä selitys kivun mahdollisista syistä ja yksilöllisten kivunhoito-ohjeiden antaminen. Vasta seurantakerralla voidaan ohjata harjoitteet kivun uusiutumisen ehkäisemiseksi. Tähän asti toteutunut fysioterapeuttien lisäkoulutuksen sisältö on painottunut tutki- miseen ja ohjaukseen alle kolme kuukautta kestäneissä selkävaivoissa. Tutkimusryhmässä oli kuitenkin mukana yli kolme kuukautta kipua kokeneita yhteensä 17 prosenttia. Tällä saattaa olla merkitystä, kun pohditaan toteutuneen ohjauksen sopivuutta tai riittävyyttä kyseiselle kohderyhmälle. Jatkossa olisi kiinnostavaa tutkia fysioterapian toteutusta ja vastetta kivun keston mukaan. Samoin jatkossa voitaisiin selvittää, onko kipualueella, koetun kivun voimakkuudella ja koetulla henkisellä kuormittumisella vaikutusta fysioterapeutin vastaanotolla koettuun hyötyyn ja kivun uusiutumiseen.

Leena Niemistön ym:iden (2005) tutkimustulosten tarkastelussa krooniset selkäkipuiset jaettiin kolmeen ryhmään, jotka olivat selviytyjät (active copers), masentuneisuuteen taipuvaiset (interpersonally distressed) ja toimintakyvyltään heikot (dysfunctional patients). Näistä ryhmistä fysioterapiasta eniten hyötyivät toimintakyvyltään heikot. STarT Back -seulontakyselyssä selkäkipuiset jaetaan kolmeen ryhmään selkäkivun uusiutumisriskin mukaan. Terapiasuosituksena matalan ja keskikorkean riskin ryhmissä painottuu fysioterapian toteutus, ja korkean uusiutumisen riskin ryhmässä suositellaan moniammatillista lähestymistä. (Robinson \& Dagfınrud 2017.) Tutkimuksessamme poissulkukriteereinä olivat ainoastaan Käypä hoito -suosituksessa mainitut punaiset liput (Pohjolainen ym. 2015).

Selkäkivun aiheuttamaa liikkumisen ja liikkeen pelkoa on esitetty yhdeksi kivun pitkittymisen ja kroonistumisen syyksi (Koho ym. 2011, Cook ym. 2006, Lundberg ym. 2004). Tässä tutkimuksessa lähes puolet ilmoitti, että fysioterapeutilla käynti vähensi selkäkivun pelkoa hyvin, mutta keskimäärin noin viidesosalla pelkoa kokeneista pelko ei helpottanut. Se, että selkäkivun pelolla, kivun uusiutumisella ja aikaisemmilla selkävaivoilla näyttää olevan yhteys, painottaa entistä enemmän sitä, että pelkoa tulisi käsitellä fysioterapeutin vastaanotolla jo heti ensimmäisellä kipujaksolla (Linton \& Shaw 2011). Mielenkiintoinen jatkotutkimuksen aihe olisi selvittää, onko samanlainen selkävaiva uusiutunut juuri niillä, jotka nyt ilmoittivat toteuttavansa ohjattuja 
harjoitteita epäsäännöllisesti. Ohjattujen harjoitteiden toteutus yksilöllisesti kullekin asiakkaalle saa tukea Lehtolan tutkimusryhmän (2016) tuloksista.

Jyväskylän ja Kuopion yliopistoissa tehdyissä fysioterapeuttien suoravastaanottoon liittyvissä kustannus-hyöty-tutkimuksissa esitetään, että hyvin toteutetulla fysioterapeuttien suoravastaanottotoiminnalla saadaan yhteiskunnalle vuosittain huomattavat säästöt (Lautamäki ym. 2016, Lakka 2008). On myös esitetty, että se, että fysioterapeutit määräävät sairauspoissaoloja yksilöllisen tarpeen mukaan, vähentää sairauslomia siihen nähden, mikä on ollut aiempi käytäntö esimerkiksi työterveyshuollossa. Tämä tuottaa suurta kustannushyötyä. (Miranda 2016, Miranda ym. 2017.) Koska tähänastisten tutkimusten taso on ollut vielä melko heikko, tarvitaan korkeatasoisia ja pitkäkestoisia seurantatutkimuksia, jotka antaisivat tietoa mahdollisten hyötyjen pysyvyydestä (Ojha ym. 2016).

\section{Tulosten luotettavuus}

Tämän tutkimuksen heikkoutena voidaan pitää vastaamatta jättäneiden suurta määrää (47 \%). Vastaamattomien taustatiedot ja selkävaivaan liittyvät tiedot eivät kuitenkaan näyttäneet poikkeavan kyselyyn vastanneiden tiedoista. Kyselyn saaneista osa oli maahan muualta muuttaneita, joiden äidinkieli ei ollut suomi eikä englanti, mikä on saattanut vaikeuttaa vastaamista. Tutkimuksen suunnittelussa olisi pitänyt paremmin ottaa huomioon eri kulttuuri- ja kielitaustat. Vastaamatta jättäneistä suurin ryhmä oli opiskelijoita, joten voidaan olettaa, että ajan puute tai postiosoitteen muuttuminen ovat voineet olla syynä vastaamattomuuteen. Lisäksi tutkimuksen heikkoutena on aineiston suhteellisen pieni koko, jolloin on mahdollisuus tyypin 1 virheeseen (so. tutkimuksen tulosten näyttö on riittävä, mutta aineiston pieni koko ei tilastollisesti tue sitä riittävästi). Kohtalaisen suuret erot ryhmien välillä (esimerkiksi 15 prosenttiyksikön ero kivun uusiutumisessa työssä olevien ja opiskelijoiden ja toisaalta eläkeläisten välillä) eivät olleet tilastollisesti merkitseviä.

\section{Johtopäätökset}

Tutkimuksen tulokset viittaavat siihen, että fysioterapeutin suoravastaanotolla käyneet asiakkaat ovat tyytyväisiä toimintaan ja ovat kokeneet saaneensa apua selkävaivaansa. Tulokset tukevat fysioterapeutin suoravastaanottotoiminnan kehittämistä, kun suunnitellaan tulevaa sosiaali- ja terveysalan uudistusta sekä toimivaa työnjakoa selkäkipuasiakkaan hoitolinjaukseen ja terveydenhuollon kustannusten vähentämiseen. Silloin, kun arvioidaan asiakkaan terapian tarvetta ja sisältöä, tulisi vielä tarkemmin kartoittaa asiakkaan mahdollisia psykososiaalisia kuormitustekijoitä (Linton \&t Shaw 2011). Ohjauksellista kehitettävää on myös siinä, miten asiakas saadaan paremmin motivoitumaan pitkäkestoiseen fysioterapeuttiseen harjoitteluun ja liikkumisen lisäämiseen. Uusintakäyntien ja sairauspoissaolojen vähenemisen pysyvyyttä ja niiden vähenemisen tuomaa mahdollista kustannushyötyä voitaisiin tarkastella vielä pidemmällä seurantaajalla. Tutkimus olisi myös aiheellista toistaa suuremmalla tutkimusjoukolla.

Tulosten merkitys: Tutkimuksen tuloksia fysioterapeuttien suoravastaanotosta voidaan hyödyntää suunniteltaessa terveydenhuoltohenkilöstön toimivampaa työnjakoa ja selkäkipuasiakkaan nopeampaa vastaanotolle pääsyä. Entistä enemmän tulee kiinnittää huomiota asiakkaan yksilölliseen ohjaukseen ja kivun hoitoon jo selkävaivan varhaisvaiheessa sekä mahdollisten psyko-sosiaalisten kuormitustekijöiden varhaiseen tunnistamiseen selkävaivojen kroonistumisen ehkäisemiseksi.

Kiitokset terveystieteiden maisteri, osastonhoitaja Jaana Ulaskalle, joka osallistui kyselylomakkeiden suunnitteluun ja laatimiseen, sekä Jyväskylän yliopiston ATK-erikoisasiantuntija Jukka-Pekka Kesoselle, joka ohjasi artikkelin tekijöitä oikeiden tilastomenetelmien valinnassa. 


\section{Tiivistelmä}

Tutkimuksen tarkoituksena oli selvittää alaselkäkipuisten asiakkaiden kokemuksia käynnistään terveyskeskuksessa fysioterapeutin suoravastaanotolla.

Tutkimus on retrospektiivinen, kuvaileva kyselytutkimus, joka toteutettiin strukturoidulla kyselylomakkeella kolme kuukautta fysioterapeutin vastaanotolla käynnin jälkeen. Lomakkeella selvitettiin selkäkivun lievittymisestä, ohjattujen harjoitteiden toteutumisesta, kivun uusiutumisesta, asiakkaan käsityksistä uusiutumisen syistä, kipuun liittyvästä pelosta, uudelleen hakeutumisesta lääkärin tai fysioterapeutin vastaanotolle ja työssäkäyvien sairauspoissaoloista. Lähetettyyn 150 kyselyyn vastasi 80 henkilöä (53 \%), jotka jakaantuivat kolmeen ryhmään: 1. eläkeläiset ( $n=26), 2$. työttömät ( = 15) ja 3. työssä olevat/opiskelijat (n = 39). Aineisto analysoitiin SPSS-tilasto-ohjelmalla ja avointen kysymysten vastaukset litteroitiin ja luokiteltiin yhtäläisyyksien mukaan.

Tulokset osoittivat, että 80-82 prosenttia asiakkaista kaikissa ryhmissä koki hyötyvänsä fysioterapeutilla käynnistään paljon tai kohtalaisesti. Kolmen kuukauden aikana selkäkivun uusiutuminen oli vähäisintä työssä olevat/opiskelijat -ryhmässä (5\%) ja suurinta eläkeläisten ryhmässä (30 \%). Saman selkäongelman vuoksi vain 10 prosenttia vastanneista hakeutui uudelleen fysioterapeutille tai lääkärille. Työssä olevien ja opiskelijoiden ryhmässä ainoastaan yksi henkilö ilmoitti olevansa kyselyhetkellä sairauslomalla.

Tutkimuksen tulokset viittaavat siihen, että fysioterapeutin suoravastaanotolla käyneet asiakkaat ovat tyytyväisiä toimintaan ja ovat kokeneet saaneensa apua selkäkipuunsa. Yhteiskunnallisen kustannus-hyöty ajattelun mukaan vähäiset uusintakäynnit fysio- terapeutin tai lääkärin vastaanotolla, sekä alhaiset sairauspoissaolot vaikuttavat merkittäviltä. Jatkossa tarvitaan korkeatasoisia, pidemmällä seurantaajalla toteutettuja satunnaistettuja tutkimuksia kustannusanalyyseineen fysioterapian varhaisesta toteuttamisesta.

Avainsanat: fysioterapia, suoravastaanotto, selkäkipu, asiakkaan tyytyväisyys

\section{Abstract}

Patients' experiences of their visit to direct access physiotherapists in the early phase of low back pain: A retrospective descriptive survey

The purpose of the study was to investigate the experiences of low back pain patients regarding their visit to direct access physiotherapists at a health center.

The study is a retrospective descriptive survey conducted in a structured questionnaire three months after a visit to a physiotherapist. The questionnaire included questions, in particular, information on the relief of back pain, the management of the instructed exercises, the recurrence of back pain, patients' perceptions of the causes of pain, the fear of pain, reasons for a repeat visit to a doctor or physiotherapist, and eventual absences due to sickness. The questionnaire was sent to 150 people who were picked up from the health care centers. Eighty (53\%) low back pain patients responded. They were divided into three groups: retired people $(\mathrm{n}=26)$; unemployed people $(\mathrm{n}=15)$; and students and employed people $(n=39)$. The data were analyzed using SPSS statistical software. The open answers were transcribed and the similarities of the answers were combined.

The results showed that $80-82 \%$ of patients in all groups experienced the 
benefits from their visit to a physiotherapist as being great or moderate. During the three months after their visit, the recurrence of back pain was at its lowest among students and employed people (5\%) and the highest among retired people (30\%). Only 10\% of the respondents made a repeat visit to a physiotherapist or doctor for the same back problem. Only one person in the students and employed people group was on sick leave.

The results show that the patients viewed the early visit to a physiotherapist as useful in the treatment of back pain and in the prevention of new episodes. From a social cost-benefit point of view the results; the low need for repeat visits to the physiotherapist or to the doctor, and the low rates of absence due to sickness let us assume those to be notable. Additional high-quality research involving longer prospective randomized designs and economic impact analyses is required to further investigate the outcomes associated with early initiation of physiotherapy.

Keywords: physiotherapy, direct access, low back pain, patients' experiences

\section{Eira Karvonen, TtM, tohtorikoulutettava, Jyväskylän yliopisto, Terveystieteiden laitos}

Markku Paatelma, TtT, ft OMT, Auron Oy

Ari Heinonen, LitT, professori, Jyväskylän yliopisto, Terveystieteiden laitoksen johtaja

\section{Lähteet}

Comerford M, Mottram S (2001) Movement and stability dysfunction-contemporary developments. Man Ther 1, 15-26.

Cook A, Brawer P, Vowles K (2006) The fear-avoidance model of chronic pain: validation and age analysis using structural equation modeling. Pain 80, 329-339.

da Silva T, Mills K, Brown BT, Herbert RD, Maher CG, Hancock MJ (2017) Risk of Recurrence of Low Back Pain: A Systematic Review. J Orthop Sports Phys Ther 5, 305-313.
Foster N, Hartvigsen J, Croft P (2012) Taken responsibility for the early assessment and treatment of patients with musculoskeletal pain: a review and critical analysis. Arthritis Research \& Therapy $14,1-9$.

Helsingin kaupunki, SOTE/fysioterapia (2011) Avofysioterapian uusi toimintamalli. Hankkeen seurantaraportti.

Häkkinen A, Korniloff K, Aartolahti E, Tarnanen S, Nikander R, Heinonen A (2014) Näyttöön perustuva tuki- ja liikuntaelinsairauksien kuntoutus. Kela, Työpapereita 68.

Kangas H, Vuori J, Luoto S (2015) Fysioterapeuttien suoravastaanotot - työnjaolla työhön tuottavuutta ja mielekkyyttä? Fysioterapia 62, 4-9.

Karvonen E, Paatelma M, Kesonen J, Heinonen A (2015) Knowledge translation from continuing education to physiotherapy practice in classifying patients with low back pain. J Manual and Manip Ther 23, 68-74.

Kinnunen M, Karvonen E (2015) Selkäkipu haltuun työfysioterapeutin vastaanotolla. Fysioterapia 62, 36-39.

Koho P, Orenius T, Kautiainen H (2011) Association of fear of movement and leisure-time physical activity among patients with chronic pain. Journal of Rehabilitation Med 43, 794-799.

Kukka A (2010) Selvitys fysioterapeuttien laajennetuista tehtäväkuvista ja tehtäväsiirroista kansainvälisesti ja Suomessa. Suomen Fysioterapeutit Finlands Fysioterapeuter ry.

Kylänen M, Vuori J, Kangas H (2015) Työnjaolla tuottavuutta ja työn mielekkyyttä. Lineaariset ja epälineaariset palveluprosessit fysioterapeuttien ja lääkäreiden työn määrittäjinä. Grano $0 y$, Kuopio.

Lakka M (2008) Selkäkipupotilas akuuttivastaanotolla. Vaikuttavuuden, käyntikohtaisten kustannusten, kustannusvaikuttavuuden ja asiakastyytyväisyyden vertailu lääkärinvastaanoton ja fysioterapeutin vastaanoton välillä. Kuopion yliopisto, terveyshallinnon ja -talouden pro gradu-tutkielma.

Lautamäki L, Salo P, Mustalampi S (2016) Fysioterapeutin suoravastaanotto - keino alentaa terveydenhuollon kustannuksia? Fysioterapia 5, 4-9.

Lehtola V, Luomajoki H, Leinonen V, Gibbons S, Airaksinen $O$ (2016) Sub-classification based specific movement control exercises are superior to general exercise in sub-acute low back pain when both are combined with manual therapy: A randomized controlled trial. BMC Musculoskelet Disord 17, 135.

Linton SJ, Shaw WS (2011) Impact of psychological factors in the experience of pain. Phys Ther 91, 700-11. 
Lundberg M, Styf J, Carlsson S (2004) A psychometric evaluation of the Tamba Scale of Kinesiophobia - from physiotherapeutic perspective. Physiother Theory Pract 20, 121-133.

Luomajoki H, Kool J, Bruin ED, Airaksinen 0 (2008) Movement control tests of the low back; evaluation of the difference between patients with low back pain and healthy controls. BMC Musculoskelet Disord 9, 170.

Lähteenmäki M-L, Leppänen P (2016) Asiantuntijafysioterapeutteja suoravastaanottotoiminnan toteuttajiksi. Tamkjournal.tamk.fi.

Miranda H (2016) Kipuoireinen asiakas työterveyshuollossa - entä jos lääkkeet, leikkaus ja sairausloma eivät autakaan? Työterveyslääkäri 1, 57-62.

Miranda H, Teerimäki R, Toikka T (2017) Uusi innovaatio kivun hoitoon ja työkyvyn tukeen. Työterveyslääkäri 2, 46-49.

Moseley G (2004) Evidence for a direct relationship between cognitive and physical change during an education intervention in people with chronic low back pain. Eur J Pain 1, 39-45.

Moseley G, Nicholas M, Hodges P (2004) A randomized controlled trial of intensive neurophysiology education in chronic low back pain. Clin J Pain 5, 324-30.

Niemistö L, Rissanen P, Sarna S, Lahtinen-Suopanki T, Lindgren KA, Hurri H (2005) Cost-effectiveness of combined manipulation, stabilizing exercises, and physician consultation compared to physician consultation alone for chronic low back pain: a prospective randomized trial with 2-year followup. Spine 30, 1109-15.

Nijs J, Van Houdenhove B (2009) From acute musculoskeletal pain to chronic widespread pain and fibromyalgia: application of pain neurophysiology in manual therapy practice. Man Ther 1, 3-12.

Ojha HA, Wyrsta NJ, Davenport TE, Egan WE, Gellhorn AC (2016) Timing of Physical Therapy Initiation for Nonsurgical Management of Musculoskeletal Disorders and Effects on Patient Outcomes: A Systematic Review. J Orthop Sports Phys Ther 2, 56-70.

O Sullivan P (2005) Diagnosis and classification of chronic low back pain disorders: maladaptive movement and motor control impairments as underlying mechanism. Man Ther 4, 242-55.

Paatelma M (2011) Physiotherapy in early phase of low back pain. Orthopedic Research and Reviews 3, 23-29.

Pohjolainen T, Leinonen V, Malmivaara A (2015) Alaselkäkipu (online). Suomalaisen Lääkäriseuran Duodecimin ja Suomen Fysiatriyhdistyksen asettama työryhmä. Helsinki: Suomalainen Lääkäri- seura Duodecim, (viitattu 27.04.2015).

Pohjolainen T, Seitsalo S, Sund R (2007) Mitä selkävaiva maksaa? Duodecim 123, 2110-5.

Robinson HS, Dagfınrud H (2017) Reliability and screening ability of the StarT Back screening tool in patients with low back pain in physiotherapy practice, a cohort study. BMC Musculoskeletal Disord 18, 232. doi: 10.1186/s12891-017-1553-X.

Ropponen M, Troberg A (2010) Varhaisvaiheen alaselkäpotilaan vastaanottotoiminta tehtävänsiirtona fysioterapeuteille perusterveydenhuollossa - kolmen ammattiryhmän kokemuksia. Opinnäytetyö, Metropolia ammattikorkeakoulu. https://publications.theseus.fi/bitstream/handle/

Suominen S (2015) Suoraan fysioterapeutin vastaanotolle. Fysioterapia 62, 2.

Suoyrjö H, Mäkiniemi E, Lehtimäki P, Joutila M (2016) Selkäpotilaan palveluketju, hankeraportti, EteläPohjanmaan sairaanhoitopiiri. www.epshp.fi/files/9462/Selkapotilaan_palveluketju.pdf.

Ylinen J (2015) Selkäpotilaan hoito perusterveydenhuollossa ja erikoissairaanhoidossa. Hoitoketjut, Keski-Suomen sairaanhoitopiiri. http://www.ksshp.fi/tules-kartta/Selkäkipupotilaanhoitoperusterveydenhuollossajaerikoissairaanhoidossa.pdf

Ylinen J, Nikander R (2014) Terveydenhuollon epätasa-arvo näkyy kuntoutuksessa. Lääkärilehti 39, 2429. 
LIITE. Asiakaskysely

1-8. Sukupuoli, ikä, paino, pituus, koulutus ym.

9. Onko yleinen terveydentilanne omasta mielestänne tällä hetkellä

10. Onko teillä ollut joitain muita sairauksia kuin selkävaiva?

11. Mikäli vastasitte kyllä, niin kirjoittakaa mitä sairauksia:

12. Oletteko joskus aikaisemman elämänne aikana käyneet selkävaivanne vuoksi lääkärillä?

13. Oletteko joskus aikaisemman elämänne aikana käyneet selkävaivanne vuoksi fysioterapeutilla?

14. Oletteko mielestänne liikunnallisesti aktiivinen?

15. Oliko viimeisistä käynnistänne fysioterapeutin vastaanotolla apua selkävaivassanne?

16. Kertoiko fysioterapeutti ymmärrettävästi selkävaivanne mahdollisista syistä?

17. Oletteko pystynyt toteuttamaan fysioterapeutin teille neuvomia kivunhoitotapoja?

18. Olivatko fysioterapeutilta saamanne ohjeet ymmärrettäviä?

19. Vähensikö käynti fysioterapeutin luona mahdollista selkäkipuun liittyvää pelkoa?

20. Kuinka monta kertaa kävitte fysioterapeuttinne vastaanotolla?

21. Ohjasiko fysioterapeuttinne teille seurantakäynnillä toimintakykynne parantamiseen liittyviä harjoitteita?

22. Oletteko tehneet fysioterapeutin teille ohjaamia harjoitteita?

23. Oletteko käyttäneet selkäkipuunne jotain muita harjoitteita tai hoitoja kuin fysioterapeuttinne ohjaamia?

24. Jos vastasitte edelliseen kysymykseen kyllä, niin kuvatkaa lyhyesti mitä harjoitteita tai hoitoja käytitte:

25. Onko selkävaivanne/ -kipunne uusiutunut fysioterapeutilla käyntinne jälkeen?

26. Jos vastasitte kyllä, niin kertokaa, kuinka pian selkäkipunne uusiutui ensimmäisen fysioterapeutilla käyntinne jälkeen?

27. Mikäli sama selkävaivanne on uusiutunut, oletteko pystynyt käyttämään fysioterapeuttinne aikaisempia ohjeita?

28. Oletteko nyt sairauslomalla saman selkävaivan vuoksi?

29. Jos olette nyt sairauslomalla, kuvatkaa lyhyesti missä toiminnoissa selkäkipunne haittaa:

30. Oletteko hakeutunut uudelleen fysioterapeutin vastaanotolle uusiutuneen selkävaivanne vuoksi?

31. Oletteko hakeutunut lääkärin vastaanotolle uusiutuneen selkävaivanne vuoksi fysioterapeutilla käyntinne jälkeen?

32. Mikäli vastasitte kyllä niin mitä hoitoja lääkäri teille määräsi?

33. Käytättekö selkäkipuunne nyt särkylääkkeitä

34. Mikäli selkävaivanne on edelleen jatkunut tai uusiutunut niin mistä itse arvelette sen johtuvan? Kertokaa omin sanoin:

35. Muita ajatuksianne, joita haluatte tuoda tietoomme toimintamme kehittämiseksi: taustatiedot

1-5 (1=erittäin hyvä, 5=erittäin huono)

$1-2(1=e i, 2=k y l l a ̈)$

$1-2(1=\mathrm{ei}, 2=\mathrm{ky} / \mathrm{lä})$

$1-2(1=e i, 2=k y l l a ̈)$

1-3 ( 1 =erittäin, $2=$ kohtalaisen, $3=$ en lainkaan)

1-3 (1=paljon, 2 =kohtalaisesti, $3=$ =ei lainkaan)

1-5 (1=erittäin hyvin, 5=ei lainkaan)

1-3 (1=hyvin, 2 =kohtalaisesti, 5=en lainkaan)

1-3 (1=kyllä, $2=$ osittain, $3=e$ i)

$1-3$ (1=kyllä, $2=e i, 3=e n$ ollut pelokas)

1-4 (1=yhden, 2=kaksi, 3=kolme, 4=enemmän kuin kolme)

1-2 (1=kyllä, $2=e i)$

1-2 (1=kyllä, $2=e i)$

1-2 (1=kyllä, 2=ei)

1-3 (1=kyllä, 2=vain osittain, 3=ei)

1-3 (1=hyvin, $2=$ =kohtalaisesti, $3=$ en ollenkaan)

1-2 (1=kyllä, 2=ei)

$1-2(1=k y l l a ̈, 2=e i)$

1-2 (1=kyllä, 2=ei)

1-3 (1=en lainkaan, 2=satunnaisesti, 3=päivittäin) 